\title{
НОВЫЙ КОМПЬЮТЕРНЫЙ МЕТОД ТЕРМИЧЕСКОГО ЭКСПРЕСС-АНАЛИЗА КАЧЕСТВА ЖИДКИХ ЧУГУНОВ ДЛЯ ПРЕДСКАЗАНИЯ МИКРОСТРУКТУРЫ И СВОЙСТВ ОТЛИВОК С ИСПОЛЬЗОВАНИЕМ РЕФЕРЕНСНЫХ КРИВЫХ ОХЛАЖДЕНИЯ
}

${ }^{1}$ Э.В. Захарченко, ${ }^{2}$ А.А. Бурбелко, ${ }^{1}$ Е.А. Сиренко, ${ }^{1}$ А.Л. Гончаров, ${ }^{1}$ А.В. Богдан

1 - Физико-технологический институт металлов и сплавов НАН Украины, г. Киев, Украина

2 - Краковская горно-металлургическая академия, г. Краков, Польша

Для эффективного управления качеством готовых отливок с заданными свойствами и минимизирования брака по вине метала очень важно определять его качество до заливки литейных форм. Таким методом определения химического состава, прогноза структуры и некоторых технологических свойств литого сплава, является термический экспресс-анализ.

Киевским физико-технологическим институтом металлов и сплавов НАН Украины совместно с Краковским университетом науки и технологии «Горно-металлургическая академия» (факультет литейного инжиниринга) разработан и верифицирован новый компьютерный метод термического анализа качества жидких чугунов для предсказания микроструктуры и свойств отливок с использованием референсных кривых охлаждения. Максимальная точность результатов обеспечивается тогда, когда сопоставляются кривые охлаждения образцов чугуна, близких по условиям выплавки и металлургической обработки [1].

В разработанном методе не используются какие-либо регрессионные соотношения между критическими температурами кривых и показателями качества расплавов. 
Метод запатентован в Украине (Патент UA№113333, 10.01.2017 г.) и успешно испытан в лабораторных и опытнопромышленных условиях на чугунах индукционной плавки [2].

Взамен широко применяемых за рубежом экологически вредных наливных песчано-смоляных пробоотборников [3] в новом методе использованы экологически безопасные и более эффективные стальные тонкостенные погружные пробоотборники.

В целом новый метод термического экспресс-анализа характеризуется универсальностью (пригоден не только для чугунов но и для многих других сплавов), самоадаптивностью (обеспечивается за счет использования референсных кривых охлаждения с металлургической предисторией, отвечающей реальным условиям конкретного литейного предприятия и требованиям действующих стандартов), быстротой и простотой (не требуется трудоемкий регрессионный анализ; используется Ньютоновский вариант термоанализа с одной термопарой и первой производной по температуре).

\section{Литература}

1. Захарченко Э.В., Жуков Л.Д., Сиренко Е.А. и др. Усовершенствование универсального метода термического экспресс-анализа жидких чугунов, основанного на распознании формы кривых охлаждения // Процессы литья. -2015 . - №2. - С. 3-9.

2. Захарченко Е.В., Сиренко К.А., Гончаров А.Л., Богдан А.В. // Пат. Украины No 99968. - 2015.

3. Binczyk F. (2007). An Assessment of the Derivative Thermal Analysis of Grey Cast Iron // Archives of Foundry Engineering. - 2007. - №7(3). - C. 2124. 